\title{
Thinking about going to university? Segmenting undergraduates
}

\author{
Marta Retamosa ${ }^{1}$, Ángel Millán ${ }^{2}$, Juan A. García ${ }^{3}$ \\ ${ }^{1}$ Department of Marketing, University of Castilla-La Mancha, Ciudad Real, Spain, \\ ${ }^{2}$ Department of Marketing, University of Castilla-La Mancha, Ciudad Real, Spain, \\ ${ }^{3}$ Department of Marketing, University of Castilla-La Mancha, Talavera de la Reina, Spain.
}

\begin{abstract}
Choosing a university is a crucial decision in a person's life because, most of the time, the acquisition of a university degree allows him access to better working conditions. Universities are interested in knowing the factors that students cite as impacting their choice of university. This study aims to classify future university students according to different evaluation criteria that could help university administrators to improve their recruitment and positioning strategies. Building on the growing body of knowledge related to the marketing of Higher Education Institutions, the current study seeks to further explore the existence of segments featuring different selection patterns. The main goal of this study was tested by applying Latent Class Analysis as a segmentation method, also referred to as Latent Class Cluster Analysis. This study found that students have different sets of motivations for their choice of Higher Education Institutions, and also found significant differences in the motivations of males and females with regard to university selection. All of these findings are of great importance to the managers of university brands, particularly at the university under study.
\end{abstract}

Keywords: undergraduate university selection process; student choice; recruitment. 


\section{Introduction}

The attention of Higher Education Institutions (HEIs) is currently focused on two main objectives: attracting new students and retaining current ones (Rowley, 2003), as universities compete with each other in the educational market for resources, prestige and students.

As the decision pattern becomes more complex and competitive, it is imperative that HEIs continually review the factors that have an impact on their choices, applying the results of this research to optimise their design of students retention and acquisition strategies.

Decisions are normally based on a combination of available information, the recommendations of third parties, perceptions of the image of the university, and the reputation of the institution (Briggs and Wilson, 2007). The way applicants access the information is usually through brochures (Connor et al., 2001), visits to universities, consultations with the staff in charge of the institution (Moogan and Baron, 2003). In some studies it has been detected that access to information often depends on social class (Christie et al., 2001). In addition, parents' perceptions of higher education institutions (HEIs) can have a significant impact on their children's choices (Parker et al., 2007).

Market segmentation is an important topic for higher education managers and researchers (Angulo-Ruiz et al., 2010). However, despite its administrative relevance, there has been little attention to segmentation in the higher education market. In order to segment it, market researchers have to consider which factors are most relevant to high school students when selecting a university. Previous studies have demonstrated the importance of rational factors, such as academic programs, economic criteria, and teaching staff. Less attention has been paid to other motivations and emotional criteria, like independence from parents, leisure facilities, and the quality of life on the university's campus and/or in its city.

This study aims to classify future university students according to different evaluation criteria that could help university administrators to improve their recruitment and positioning strategies. Building on the growing body of knowledge on the marketing of Higher Education Institutions, the current study seeks to further explore the existence of segments presenting different selection patterns. 


\section{Theorical background}

A review of the main studies on the selection criteria of future HEI students is presented in Table 1.

Table 1. Main authors and contributions on the selection criteria of future HEI students.

\begin{tabular}{|c|c|}
\hline AUTHOR(S) & MAIN CONTRIBUTION \\
\hline $\begin{array}{l}\text { Connor et al. } \\
\qquad(2001)\end{array}$ & $\begin{array}{l}\text { Survey of future students in Scotland. These authors found that the suitability } \\
\text { of the subjects taught at the university was the most influential factor. Other } \\
\text { factors included job prospects, the reputation of the teaching, the university's } \\
\text { image, acceptance requirements, academic support facilities, and location. }\end{array}$ \\
\hline $\begin{array}{l}\text { Soutar and } \\
\text { Turner } \\
(\mathbf{2 0 0 2})\end{array}$ & $\begin{array}{l}\text { The author analysed the importance of a number of attributes to graduating } \\
\text { high school students in Australia. The results indicate that the four most } \\
\text { important factors determining university preference were: course suitability, } \\
\text { academic reputation, job prospects, and teaching quality. }\end{array}$ \\
\hline $\begin{array}{l}\text { Moogan and } \\
\text { Baron } \\
(\mathbf{2 0 0 3 )}\end{array}$ & $\begin{array}{l}\text { Survey at six universities in Great Britain. The results demonstrated that during } \\
\text { the evaluation of alternatives phase, course content was more important to } \\
\text { females, whereas reputation was more important to males. The most critical } \\
\text { factor in causing apprehension was that of grade expectations, with females } \\
\text { being less confident than males about having the necessary entry qualifications. }\end{array}$ \\
\hline Pimpa & $\begin{array}{l}\text { This study examines the influence of family on students from Thailand. It } \\
\text { proves that financial influence is the strongest family influencing factors and } \\
\text { family expectations is the second. }\end{array}$ \\
\hline Briggs & $\begin{array}{l}\text { This article explores the factors influencing student choice at six contrasting } \\
\text { Scottish universities. Results illustrate consistency in respect to the top three } \\
\text { factors: academic reputation, distance from home and location. }\end{array}$ \\
\hline $\begin{array}{l}\text { Hagel and Shaw } \\
\qquad(2008)\end{array}$ & $\begin{array}{l}\text { Survey of future students at an Australian university. The findings from the } \\
\text { study indicate that the most important reasons were: study mode, tuition and } \\
\text { university reputation. }\end{array}$ \\
\hline $\begin{array}{l}\text { Joseph } \text { et al. } \\
\qquad(2012)\end{array}$ & $\begin{array}{l}\text { Exploratory study using survey data at two universities in the United States. } \\
\text { The importance of university selection criteria differs between those who } \\
\text { attend public and private institutions. } \\
\text { - Private university students appear to value reputation, selectivity, personal } \\
\text { interaction, facilities and cost; whereas public university students value } \\
\text { programmes, athletics, reputation, cost, housing and location. } \\
\text { "Reputation" for students at public institutions was limited to perceptions } \\
\text { of quality education and accreditation, while students at private } \\
\text { institutions saw reputation as including name recognition and the renown } \\
\text { of the university/department. }\end{array}$ \\
\hline $\begin{array}{l}\text { Chen and } \\
\text { Zerquera (2018) }\end{array}$ & $\begin{array}{l}\text { This study utilized data obtained from } 7,688 \text { students residing in the tri-country } \\
\text { metropolitan area in USA. They conclude that students with higher academic } \\
\text { achievement ar more likely to enrol at colleges further from home, perhaps } \\
\text { because they recruited by more selective institutions. Family socioeconomic } \\
\text { status plays a significant role in college access and choice. }\end{array}$ \\
\hline $\begin{array}{l}\text { Haywood and } \\
\text { Scullion } \\
(2018)\end{array}$ & $\begin{array}{l}\text { Focused on parents, an under-researched group. The results indicated that they } \\
\text { experience this process primarily as parents, not consumers, and that their } \\
\text { desire to maintain their relationships at this critical juncture is more important } \\
\text { to them than the choice of particular academic programmes and universities. }\end{array}$ \\
\hline
\end{tabular}


Choices by students do not follow a simple linear or rational process. Rather, the selection of a university involves a complex process affected by numerous factors, such as cost, information available, the way to access the university, academic achievements, and campus life and experiences (Foskett and Hemsley-Brown, 2001; Moogan and Baron, 2003). There is a consensus at the international level that students' choices depend on multiple factors (Connor et al., 2001, Kinzie et al., 2004) and a growing recognition of the need to understand the most decisive factors in the selection of a university (Connor et al., 2001).

However, there are few studies that have researched how students really analyse and weigh these attributes. A widely used method to examine alternatives in decision-making is joint analysis, which allows preferences to be broken down into their constituent parts (Hagel and Shaw, 2008). Three published studies have reported findings with respect to the selection of universities using this method (Hooley and Lynch, 1981, Soutar and Turner, 2002, Moogan and Baron, 2003). The results of the three studies on the relative importance of the degree/curriculum offered, academic reputation, and location, were consistent with the existing literature, although none of these studies included academic fees and costs in their criteria. In addition, it is assumed that students conceive of their choices as based on sets of characteristics, and prefer these specific ones over the products as a whole (Hagel and Shaw, 2008).

However, it is worthwhile to consider whether this set of characteristics is exhaustive and still valid. Recent studies, such as that by Kinzie et al. (2004), have found that the factors that impacted choices in the 1990s are similar to those identified in surveys from the 1960s, in which importance was attached to the curriculum; the usefulness, or employability, of the education; recommendations by third parties, and the social side of university life.

Taking into account this background, it is necessary to make a continuous market research effort in order to understand students' choice criteria.

\section{Method}

\subsection{Data collection and Instrument}

A personal survey was used with fixed-alternative questions measured on a 10-point Likert scale. 605 questionnaires were considered before removing the incomplete or incorrectly completed ones. With regard to the total group of students surveyed, $44.3 \%$ were men and $55.7 \%$ were women. The questionnaire includes 9 criteria obtained from previous studies, such as that by Joseph et al. (2005), and two focus group with university administrators in charge of student recruitment and communication campaigns. 


\section{Results}

\subsection{Model fit}

The main goal of this study was tested by applying Latent Class Analysis as a segmentation method, also referred to as Latent Class Cluster Analysis (LCCA) because of its significant advantages over other segmentation procedures. The parameter estimation model was carried out using Latent Gold ${ }^{\circledR}$ 4.5. The results indicated that there were five groups of student groups, according to the BIC and CAIC criteria.

\subsection{Parameters}

Once the number of clusters had been established (five), the significance of the indicators and covariates was evaluated. On the one hand, the p-value associated with the robust Wald statistic was less than 05 for all the indicators, indicating that these were a significant contribution toward discriminating between the five clusters considered.

\subsection{Clusters'profile}

The main characteristics of the clusters of students are the following (see Table 2):

Table 2. Means and characteristics for clusters.

\begin{tabular}{ccccccc}
\hline CLUSTER (SIZE) & $\mathbf{C . 1}$ & $\mathbf{C . 2}$ & $\mathbf{C . 3}$ & $\mathbf{C . 4}$ & $\mathbf{C . 5}$ & TOTAL \\
& $(38.2 \%)$ & $(31.9 \%)$ & $(11.2 \%)$ & $(9.7 \%)$ & $(9.1 \%)$ & \\
\hline High school teachers' advice & 3.0 & 3.9 & 3.0 & 1.8 & 4.1 & 3.2 \\
Economic aspects (family income) & 4.6 & 5.7 & 5.2 & 4.8 & 5.5 & 5.1 \\
Grades for admission & 7.2 & 7.8 & 5.5 & 7.0 & 7.6 & 7.2 \\
Social activities/City night life & 5.1 & 7.1 & 3.5 & 6.8 & 9.0 & 6.1 \\
Becoming independent from parents & 6.5 & 8.0 & 2.0 & 9.9 & 9.9 & 7.1 \\
$\quad$ City's quality of life & 6.9 & 8.4 & 4.4 & 9.8 & 9.9 & 7.6 \\
Accommodation cost (rentals) & 6.9 & 8.2 & 3.4 & 8.7 & 9.8 & 7.4 \\
Study abroad programmes & 5.2 & 8.1 & 5.3 & 5.4 & 8.5 & 6.4 \\
Internships/practicum programs & 6.3 & 8.5 & 6.2 & 5.5 & 9.5 & 7.2 \\
\hline
\end{tabular}

Cluster 1. HIGH ACADEMIC PERFORMANCE. This group is primarily made up of men, at $52.4 \%$. Grades are an important reason for them (value of the affirmation equal to the average). However, it is the group that assigns least importance to economic aspects. 
They seek access to degree programmes related to Science and Technology (Engineering and Science), which require high grades for acceptance.

Cluster 2. HIGH ACADEMIC PERFORMANCE BUT ECONOMY AND WOM. This group is made up primarily of women (59.5\%). They assign the highest priority, of all the groups, to economic factors and the grades required for acceptance to the university. They also stand out because they taken into account, more than the average across the sample, the recommendations of teachers at their high schools.

Cluster 3. UNCONCERNED. This group presents scores below the average in almost all criteria. They only assign more importance to economic criteria. This group is made up primarily of women $(52.6 \%)$.

Cluster 4. BEING INDEPENDENT OF PARENTS. This group, women in their majority $(67.7 \%)$, values, above the average, and with very high scores, living away from home and independent of their parents. They also take into account the quality of life in the city chosen. This group also stands out for being the least influenced by the recommendations of teaching staff, and that which attaches the least importance to economic aspects, together with Cluster 1.

Cluster 5. OVERINFORMED. They value all the criteria above the average in comparison with the rest of the groups. They take into account all the selection factors when making their decision and, therefore, a much more complex process to choose their universities and study programmes is to be expected. As a characteristic setting them apart, they are the group that most values the opportunity to study abroad, and internships at companies, when making their decision. They are mostly women (67.3\%).

\section{Conclusions}

This study found that students have different sets of motivation for their choice of HEIs. At the practical level of universities' marketing and recruitment strategies, the considerable differences found can explain why some communication campaigns and information media failed, whereas others have not yet convincingly demonstrated that they are successful and/or sustainable (Becker, 2009; Wilkins et al., 2011). Therefore, the appeal of a university's brand depends greatly on the ability to focus on consumers' specific needs and desires, which is why defining the target for each college helps to bolster the effectiveness of recruitment and brand strategies. The same conclusions were drawn by previous studies, like that by Bock et al. (2014).

Our study also found significant differences in the motivations of males and females. Males are more concerned with academic performance, while females consider a great variety of choice criteria. These findings are consistent with those of previous studies (Shanka et al., 
2005; Maringe, 2006). When choice criteria are combined with a consideration of these gender differences, it is possible to identify distinct and different segments requiring different marketing and recruitment approaches by universities (Hemsley-Brown, 2017). This approach can be a more effective way to extend the traditional segments and increase student satisfaction, especially with some degree programmes that are mostly oriented towards men or women, such as Engineering, and Nursing, respectively.

Additionally, the size of the different segments identified also has important practical implications for the university under study. Thus, given that the first two segments account for almost $70 \%$ of the sample, it seems evident that the university analysed should focus its communication efforts on three aspects. Firstly, it should make an effort to encourage high school teaching staff to recommend the university. Second, taking into account the great importance of academic performance to both Cluster 1 and 2, instruments could be devised -such as search engines, comparison tools etc.- clarifying the number of spots available and the latest grades required for the different degree programmes offered. Thirdly, studies should clearly communicate the advantages in terms of cost (tuition, accommodations, transportation, residence, etc.) of the university studied with respect to its competition.

Starting from the possibility of extrapolating the results to other universities, the UCLM would be a public institution not comparable in its management with private ones or universities outside the Spanish university context. Although this study has been conducted in the context of a Spanish university, it nonetheless has relevance and contributes to the marketing managers across all universities.

\section{References}

Angulo-Ruiz, F., Pergelova, A. and Rialp, J. (2010). A market segmentation approach for higher education based on rational and emotional factors. Journal of Marketing for Higher Education, 20(1), 1-17.

Becker, R.F.J. (2009). International Branch Campuses. London, UK: Observatory on Borderless Higher Education.

Bock, D.E., Martin-Poole, S. and Mathew, J. (2014). Does branding impact student recruitmen: A critical evaluation. Journal of Marketing for Higher Education, 24,11-21.

Briggs, S. (2006). An exploratory study of the factors influencing undergraduate student choice: the case of higher education in Scotland. Studies in Higher Education, 31(6), 705-722.

Briggs, S., and Wilson, A. (2007). Which university? A study of the influence of cost and information factors on Scottish undergraduate choice. Journal of Higher Education Policy and Management, 29(1), 57-72.

Chen, J., \& Zerquera, D. (2018). Leaving or Staying Home: Predicting Where Students Attend College. Education and Urban Society, 50(4), 376-399.

Christie, H., Munro, M.A. and Rettig, H. (2001). Making ends meet: Student incomes and debt. Studies in Higher Education, 26(3), 363-383. 
Connor, H., Burton, R., Pearson, R., Pollard, E. and Regan, J. (2001). Making the right choice: how students choose universities and colleges. London, UK: Institute for Employment Studies/Committee of Vice-Chancellors and Principals.

Foskett, N.H. and Hemsley-Brown, J.V. (2001). Choosing futures: Young people's decision-making in education, training and careers markets. London, UK: Routledge Falmer.

Hagel, P. and Shaw, R. (2008). The influence of Delivery Mode on Consumer Choice of University. European Advances in Consumer Research, 8, 531-536.

Haywood, H. and Scullion, R. (2018). It's Quite difficult letting them go, isnt't it?.UK parents' experiences of their child's higher education choice process. Studies in Higher Education, 43(12), 2161-2175.

Hemsley-Brown, J. (2017). Higher education segmentation, In Teixeira, P. and Shin, J.C. (eds.), Encyclopedia of International Higher Education Systems and Institutions, Springer, Netherlands.

Hooley, G.J. and Lynch, J.E. (1981). Modelling the Student University Choice Process through the use of Conjoint Measurement Techniques. European Research, 9(4), 158170.

Joseph, M., Wall Mullen, E. and Spake, D. (2012). University branding: Understanding students' choice of an educational institution. Journal of Brand Management, 20(1),112.

Joseph, M., Yakhou, M. and Stone, G. (2005). An educational institution's quest for service quality: customers' perspective. Quality Assurance in Education, 13(1), 66-82.

Kinzie, J.P., Hayek, M., Hossler, J., Jacob, D. and Cummings, H. (2004). Fifty years of college choice: Social, political and institutional influences on the decision-making process. Lumina Foundation for Education, New Agenda Series, 3(5), 1-72.

Maringe, F. (2006). University and course choice: Implications for positioning, recruitment and marketing, International Journal of Educational Management, 20(6), 466-479.

Moogan, Y.J. and Baron, S. (2003). An analysis of student characteristics within the student decision-making process. Journal of Further and Higher Education, 27(3), 271-287.

Parker, R. S., Cook, S. and Pettijohn, C. E. (2007). School choice attributes: Positioning a private school. Services Marketing Quarterly, 28(4), 21-33.

Pimpa, N. (2005). A family affair: The effect of family on Thai students' choices of international education. Higher Education, 49(4), 431-448.

Rowley, J. (2003). Retention: Rhetoric or realistic agendas for the future of higher education. International Journal of Educational Management, 17(6), 248-253.

Shanka, T, Quintal, V. and Taylor, R. (2005). Factors influencing international students' choice of an education destination - A correspondence analysis. Journal of Marketing for Higher Education, 15(2), 31-46.

Soutar, G.N. and Turner, J.P. (2002). Students' preferences for university: A conjoint analysis. International Journal of Educational Management, 16(1), 40-45.

Wilkins, S., Balakrishnan, M.S. and Huisman, J. (2011). Student choice in higher education: Motivations for choosing to study at an international branch campus. Journal of Studies in International Education, 16(5), 413-433. 